
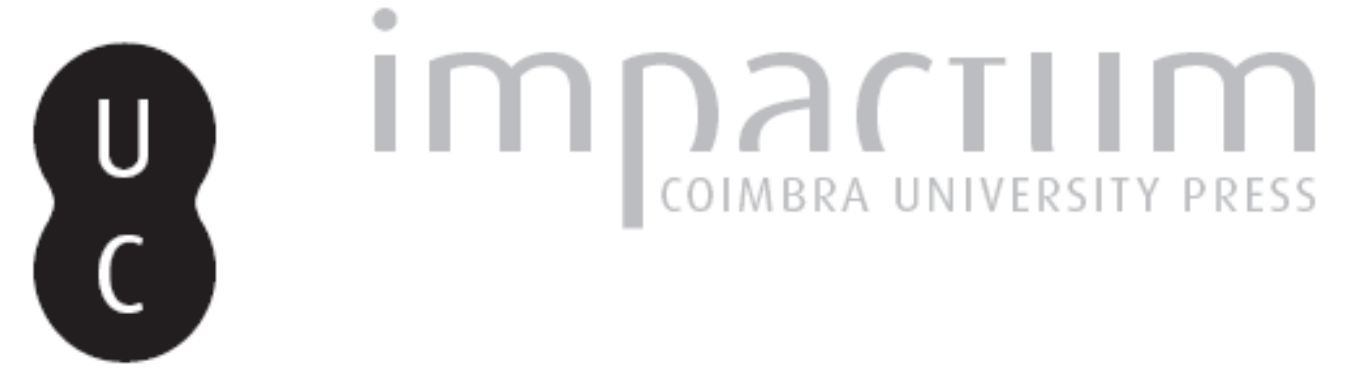

\title{
Música das Cidades: o Surgimento da Canção Popular Moderna como Forma de Representação do Indivíduo
}

\author{
Autor(es): $\quad$ Cespedes, Fernando Garbini \\ Publicado por: Imprensa da Universidade de Coimbra \\ URL \\ persistente: \\ URI:http://hdl.handle.net/10316.2/43203 \\ DOI: \\ DOI:https://doi.org/10.14195/2183-6019_5_6
}

Accessed : $\quad$ 26-Apr-2023 15:47:48

A navegação consulta e descarregamento dos títulos inseridos nas Bibliotecas Digitais UC Digitalis, UC Pombalina e UC Impactum, pressupõem a aceitação plena e sem reservas dos Termos e Condições de Uso destas Bibliotecas Digitais, disponíveis em https://digitalis.uc.pt/pt-pt/termos.

Conforme exposto nos referidos Termos e Condições de Uso, o descarregamento de títulos de acesso restrito requer uma licença válida de autorização devendo o utilizador aceder ao(s) documento(s) a partir de um endereço de IP da instituição detentora da supramencionada licença.

Ao utilizador é apenas permitido o descarregamento para uso pessoal, pelo que o emprego do(s) título(s) descarregado(s) para outro fim, designadamente comercial, carece de autorização do respetivo autor ou editor da obra.

Na medida em que todas as obras da UC Digitalis se encontram protegidas pelo Código do Direito de Autor e Direitos Conexos e demais legislação aplicável, toda a cópia, parcial ou total, deste documento, nos casos em que é legalmente admitida, deverá conter ou fazer-se acompanhar por este aviso.

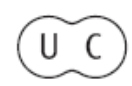


revista de comunicação,

jornalismo e espaço público

\section{5}

Periodicidade

Semestral

Imprensa da Universidade de Coimbra

Coimbra University Press

\section{mediapolis}

crises e os processos comunicativos

crisis and communicative process

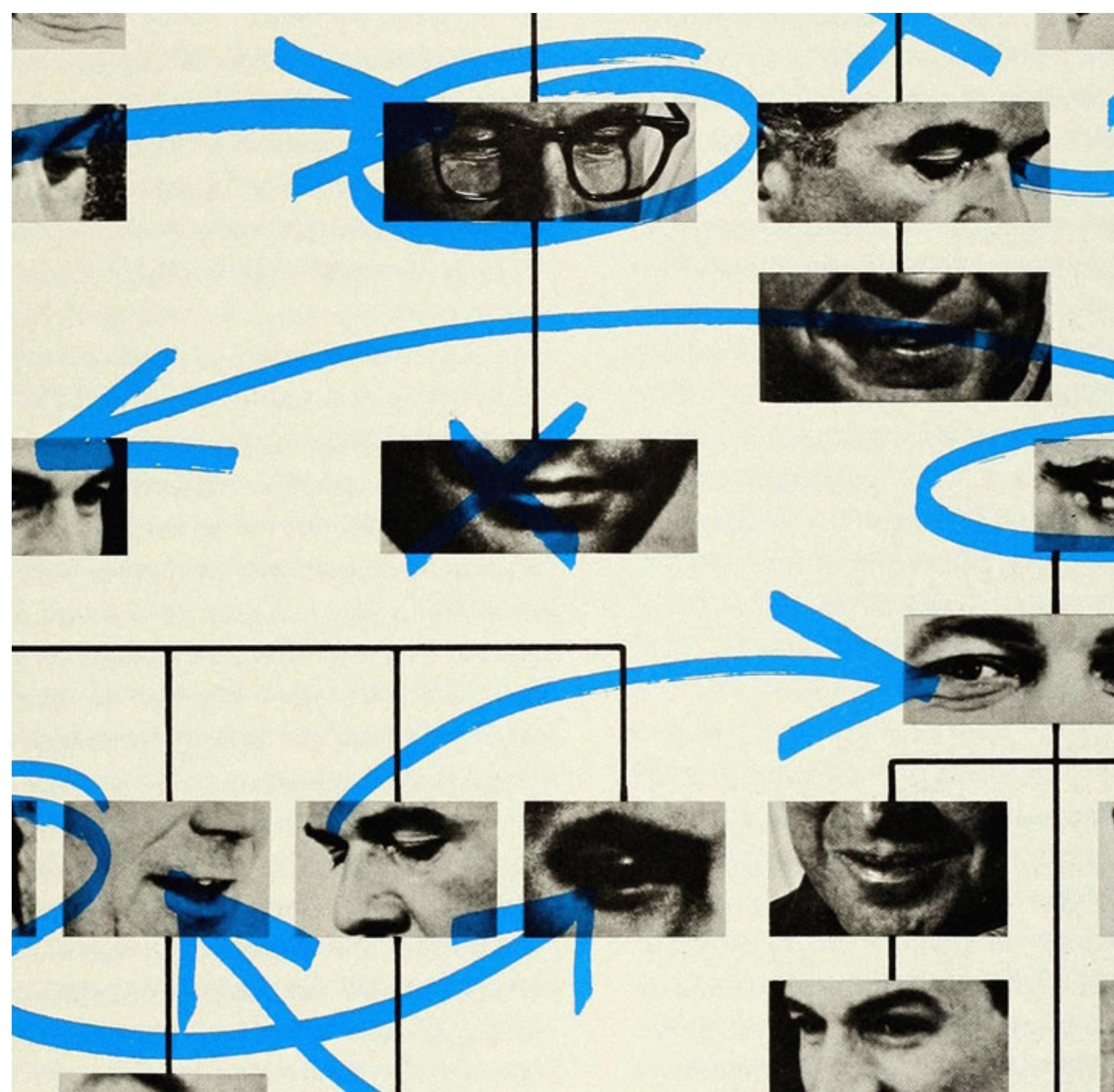




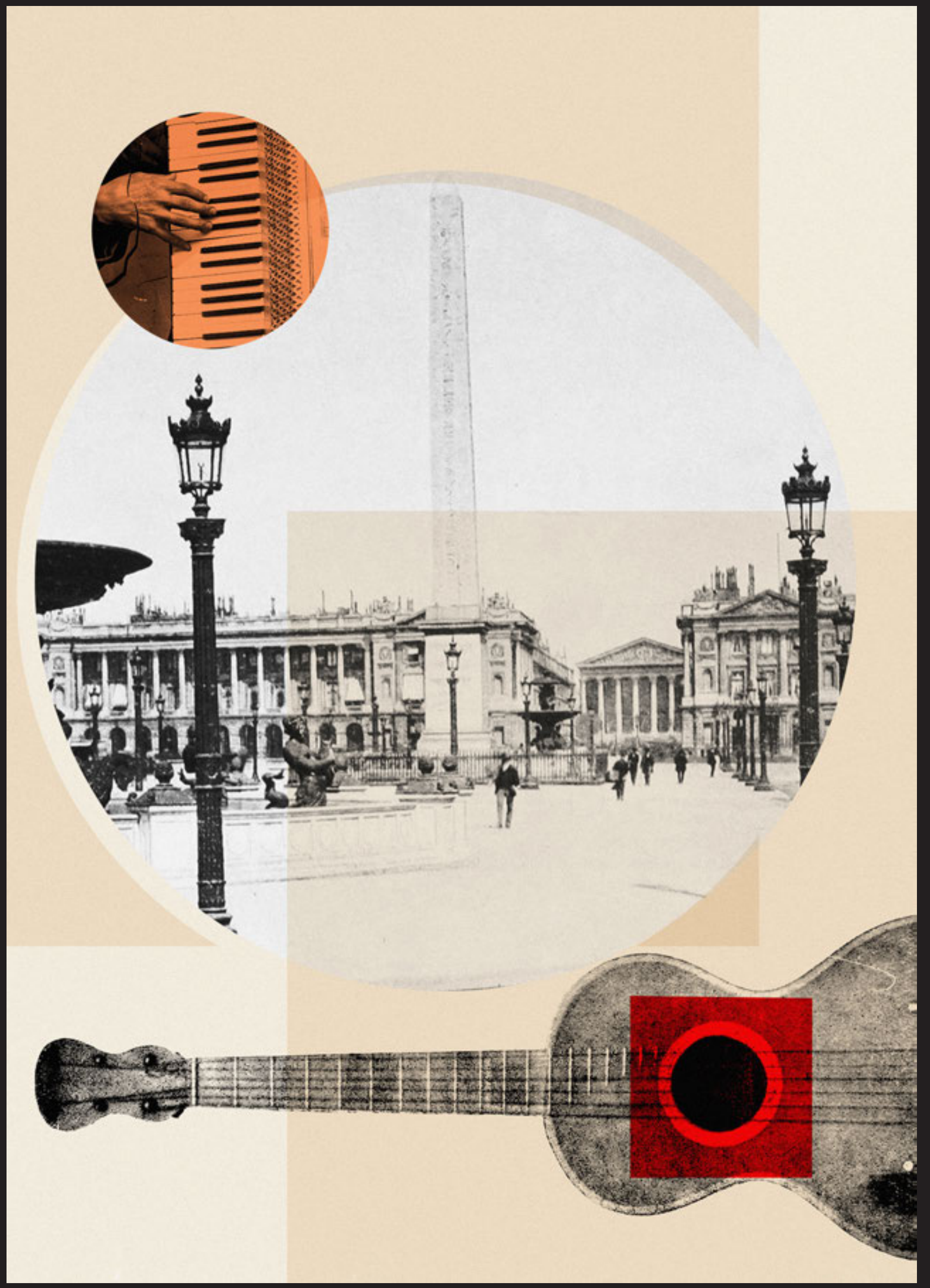




\title{
Música das Cidades:
}

\section{O Surgimento da Canção Popular Moderna como Forma de Representação do Indivíduo}

\author{
Music of the Cities: The Emergence of the Modern Popular Song \\ as a Representation of the Individual
}

https://doi.org/10.14195/2183-6019_5_6

\section{Resumo}

Nossa relação com a música é um jogo de representação que começa na consciência dos ritmos biológico-corporais e da natureza, nas aventuras percussivas e experiências sonoras dos hominídeos. Nos primeiros estágios do desenvolvimento humano, a ideia de indivíduo ainda não existia. Vivíamos, da Pré-História à Idade Antiga, sob distintas formas de consciência coletiva, que faziam com que as formas de expressão humanas, incluindo as musicais, surgissem de maneira não individual, mas comunitária. Nesse contexto, o surgimento, na Era Moderna, das metrópoles, com suas multidões e formas de organização social, é marco fundamental na formação do indivíduo e da canção popular, por ele composta e apreciada.

Aqui, analiso - por meio da revisão de relatos históricos contextuais e de reflexões gerais acerca dos temas de interesse - o papel das cidades como berço da canção popular moderna no contexto do surgimento do indivíduo, com o objetivo de posicionar a canção como o equivalente musical do conceito de indivíduo como hoje o conhecemos. Nas ruas de Lisboa, Nápoles e Paris entre os séculos XVI e XIX, distintas heranças musicais se fundem sob novas formas de produção de sentido, organização social, política e econômica forjando lundus e modinhas luso-brasileiros, canzones napoletanas e chansons du vaudeville parisiense e, com elas, o indivíduo moderno ocidental.

Palavras-chave: canção popular moderna; música popular; modernidade; cidades; indivíduo; subjetividade.

\section{Abstract:}

Our relationship with music is a portrayal game that starts with the awareness of bodily and biological rhythms and with the percussive adventures of the hominids. Back then, the concept of an individual human being as oneself had yet to be established. Humans lived under an all-inclusive, collective consciousness similar to that of pack of animals. This communitarian condition has led the way for the development of collective forms of human expression (later to be described as culture), including sonic ones such as music.

In this context, the rise of Western cities in the Modern Era represents a landmark for a specific form of music, the popular song, and along with it, the consolidation of the concept of a uniquely human "self". My goal is to present cities as cradle of the modern pop song. In the streets of Lisbon, Naples and Paris, distinct musical heritages are blended together under newly developed forms of intellectual, social, political and economic organization to forge the Brazilian/Portuguese lundus and modinhas, the canzone napoletana and the Parisian vaudeville chanson and, with them, the modern concept of being

Keywords: modern pop song; popular music; Modern Era; cities; being; subjectivity. 


\section{A música que emana do povo}

Houve uma época não muito distante no Ocidente em que as músicas populares - assim como os mitos, contos de fadas e lendas - não eram compostas, elas simplesmente surgiam. Os Irmãos Grimm, não só autores, mas também pesquisadores do folclore, se referiam a esse fenômeno como Naturpoesie, «poesia natural que emanava da alma do povo, em contraste com a literatura cultivada (Kunstpoesie), produzida por um autor» (Schmiesing, 2014). Numa época em que a História ainda não tinha a pretensão de dar conta de todas as coisas, a oralidade encarregava-se de tocar adiante as tradições musicais populares, sem registro ou controle em relação ao seu surgimento.

Não me refiro, contudo, apenas à Antiguidade, na qual um hipotético conceito de autoria dilui-se nos próprios modos de produção familiares e coletivos. Tampouco, mais à frente na Idade Antiga, poderíamos falar em obra de arte, pois esta era uma burocracia ainda a ser inventada: o que à frente seria dividido entre música, dança, pintura, escultura ou teatro eram faces indivisíveis dos mesmos rituais comunitários, místicos e religiosos inerentes à maioria dos povos. No tempo em questão, já estavam plenamente estabelecidas as noções modernas de propriedade privada e comércio, além de sistemas e convenções monetárias e pagamento de tributos. Entretanto, no que se refere às práticas musicais populares do Ocidente nos idos de 1500:

a atitude mais tradicional era a que (...) nenhum apresentador admitiria ter composto uma nova canção. «Todos negam a responsabilidade, mesmo o verdadeiro compositor, e eles dizem que a ouviram de uma terceira pessoa. (Wilson, 2010).

$\mathrm{O}$ anonimato sob o qual as antigas formas de música popular apoiam-se nasce do pacto não-verbal entre apresentador e público: ambos sabem que o que cantam, tocam e ouvem não é passível de ser criado por homens comuns, é, sim, fruto da tradição. Autenticidade e novidade não faziam, naquele momento, parte do conjunto de valores apreciados pelo grande público dos estratos mais baixos das populações europeias. De forma geral, motivos, temas, fórmulas e esquemas musicais eram permutados, ornamentados e transformados segundo variações conhecidas, cabendo aos apresentadores darem suas contribuições pontuais, seja sob a forma de pequenas improvisações melódicas no canto ou no instrumento, seja adaptando a história ao público de ocasião. Não havia forma, sequência ou melodia correta, mas sim linhas gerais a serem seguidas.

Ao apresentador tampouco interessava alardear sua autoria. Num mundo sem copyrights, contratos ou formas mecânicas de reprodução musical, só o ato performático possuía algum valor. Revelar-se como autor seria, mais ainda, ver o poder de sua obra diluir-se, sua aura mágica de familiaridade arrefecer junto ao público, não mais ancorada pela inquestionável solidariedade da experiência coletiva. $\mathrm{O}$ valor estético estava no conhecido, no comum, no próximo. Mais do que isso, a própria fronteira entre apresentador e público não era clara: sendo 
a música popular manifestação que emana do povo, entidade sem rosto ou nome próprio, todos sentiam-se parte integrante dela. Naquele momento histórico, convencionou-se chamar de povo tudo aquilo que:

era natural, simples, analfabeto, instintivo, irracional, enraizado na tradição e no solo da região, sem nenhum sentido de individualidade (o indivíduo se dispersava na comunidade) (Burke, 2010: 33).

Era normal, portanto, que a música, por si só cercada de certa aura mística, proveniente do povo, fosse vista como algo surgido espontaneamente e sem processo definido, assim como as lendas, costumes e tradições.

Essa visão comunitária das expressões musicais, caracterizada por uma empatia total, é fruto das formas ancestrais de organização social calcadas em nossa história cognitiva e biológica. Retrocedendo em nossa história como humanidade, lembramos que os pilares de nosso entendimento do indivíduo consciente são recentes na história humana. Entre esses pilares estão nossa capacidade de dissimular, nossas noções de privacidade e limites corporais, e o reconhecimento da vontade e livre-arbítrio em si próprio e no outro. Surgimos, insisto, como espécie, unidos por fortes laços que fundem o fisiológico no psicológico, e que, por incontáveis gerações, nos fizeram identificar a nós mesmos não como indivíduos, mas como partes de um ser coletivo.

A coesão dessa consciência coletiva se manteve intacta pela própria forma com que enxergávamos o outro, pois «durante a maior parte do processo evolutivo, quase tudo aquilo que os indivíduos sentiram e pensaram era tão transparente que, para outros ao redor, essas experiências eram como se fossem deles mesmos» (Sloterdijk, 2014: 264). No momento histórico ocidental da baixa Idade Média, a espécie humana já havia se autoproclamado, há muito, herdeira única do mundo. Entretanto, apesar da notável capacidade intelectual, de todas as invenções, tecnologias, conquistas e feitos, estávamos ainda inseridos numa condição de subjetividade coletiva de bando.
Contudo, talvez essa condição jamais tenha afetado a humanidade de forma homogênea. Ainda que compartilhemos raízes biológicas, as diversas formas de organização social, política e econômica, e suas respectivas hierarquias, foram levando a pequenas e pontuais emancipações da condição coletiva primordial. Assim, o distanciamento da condição natural de bando rumo à autossuficiência do indivíduo, consciente e dono de si, é um processo histórico que surge de forma perpendicular à distribuição dos diversos estratos sociais.

O processo se desenrola a partir do topo da pirâmide, motivado pelas necessidades de distinção social comum a todos os tipo de elite, e, particularmente, desta elite europeia que se alimenta dos ideais do Renascimento e, em seguida, do Iluminismo para alçar seus membros a uma nova condição de indivíduo consciente de sua individualidade.

Naquele momento, camponeses e pequenos artesãos medievais vinculavam-se ao mundo apenas por meio dos grupos aos quais pertenciam (núcleos 
familiares e profissionais), e que, por sua vez, delimitavam funções dentro de uma inexistente mobilidade social. Ao mesmo tempo, membros da nobreza, motivados pela ascensão do antropocentrismo, desenvolviam gradativamente atributos ligados ao conceito moderno de indivíduo: consciência, esclarecimento, personalidade e aspirações.

Esse processo, que permitiu ao indivíduo reconhecer-se como responsável pela criação de determinada manifestação estética, já havia tomado forma no discurso literário desde a Baixa Idade Média e teve como evento central:

$$
\begin{aligned}
& \text { a emergência, nos comentários } \\
& \text { bíblicos, da visão de que o autor } \\
& \text { humano possuía um alto status e } \\
& \text { notáveis estratégias de didáticas e } \\
& \text { estilísticas - em suma, a auctoritas } \\
& \text { moveu-se do reino divino para o } \\
& \text { humano (Minnis, 2012: XXVII). }
\end{aligned}
$$

Ainda que grande parte das manifestações musicais (seja na concepção, execução ou recepção) ainda pertencesse à coletividade, já havia momentos isolados nos quais indivíduos poderiam emancipar-se e criar música a partir de uma nova subjetividade individual. Inicialmente restrito às elites cortesãs, esse processo passa a atingir as camadas populares gradualmente à medida que os grandes centros urbanos tornam-se o novo espaço social da vida europeia. É deste processo que aqui nos ocupamos: um ciclo de retroalimentação entre canção e indivíduo, impulsionado pelas novas dinâmicas e espaços sociais urbanos e que deu novos significados à cultura popular. Daí, o foco nas metrópoles europeias que, de forma decisiva, contribuíram para ajudar a esclarecer como se deu, no Ocidente, a passagem da música de sentido coletivo para o individualismo da canção entre os séculos XVI e XIX.

\section{A canção popular moderna e suas características}

Se a canção é anterior ao tempo aqui retratado, de que falo quando falo de canção popular moderna? Trato de uma forma de expressão musical forjada a partir do século XVI nos espaços sociais das cidades por seus novos habitantes: os indivíduos. Falo de um vasto conjunto de gêneros musicais que estabelecem relação intrínseca e coerente entre as palavras cantadas melodicamente (a letra) e o acompanhamento harmônico. Em relação ao ritmo da voz, o canto flui de forma sincopada (que desloca a acentuação por entre os tempos fortes e fracos do compasso musical), fruto da prosódia das novas línguas latinas, que, ao contrário do grego e do latim puro, são marcadas pela acentuação tônica.

Uma das características mais marcantes da canção popular moderna é que ela, ao contrário da canção popular tradicional, tem autoria e letras definidas e expressa o ponto de vista subjetivo do autor sobre determinado assunto. Os temas giram em torno de ilusões e desilusões amorosas, sátiras do cotidiano ou pequenas crônicas citadinas (em oposição aos temas mítico-épicos dos primórdios da canção, substituídos depois pelos étnico-nacionais).

Embora haja exceções, é comum que o autor da canção acumule as 
funções de instrumentista e cantor solo. A figura do cantor solo contrapõe-se aos cantos coletivos, prática mais comum nas tradições litúrgica e profana, seja em corais religiosos, seja em cantos de festas ou trabalho.

O canto solo está presente na grande maioria dos relatos históricos sobre antigas culturas musicais, porém, geralmente como parte integrante da forma, não como seu elemento principal. Quando apareciada como protagonista, representava, como na dramaturgia, um personagem, sendo o cantor um mero porta-voz. $\mathrm{O}$ canto solo, que representa as ideias e vontades de quem canta, é atributo central da canção popular moderna e traduz a ascensão do indivíduo frente à coletividade.

Considerando o lado funcional, o que antes existia apenas para cumprir funções coletivas essenciais passou a servir também à vontade individual. Antes, a música era via para a comunhão e o diálogo com os deuses, transmitia tradições e mitos do passado, fortalecia exércitos, coordenava o trabalho, afastava demônios e garantia a boa colheita. Para aqueles agora aptos a dominá-los, os sons musicais tornaram-se matéria-prima para expressão de desejos e caprichos que não encontravam mais correspondência no coletivo. Assim, o processo histórico que fez com que o indivíduo se tornasse apto a criar sua própria música, teve, como efeito, a dessacralização da prática musical.

Mais ainda, a canção popular moderna nasce com funções sociais bem determinadas. Ela surge respondendo a um anseio inédito, fruto de uma nova sociedade, cujos meios de produção não eram mais aqueles ligados ao sistema feudal. No começo da Era Moderna, as cidades nas quais a canção popular nasceu já eram grandes centros urbanos. Em comum, tinham a pluralidade cultural típica dos impérios coloniais e, principalmente, populações dispostas em complexos arranjos de relações sociais baseadas em novas divisões do trabalho. É nesse ambiente social mais livre e dinâmico - já liberado dos arcaicos laços da servidão feudal - que uma grande transformação: ia ficar patente não apenas nas mudanças de comportamento das pessoas, mas na própria composição da sociedade: com o afrouxamento dos laços que compunham o antigo sistema, a teia social se rompe aqui e ali, deixando aparecer as pontas soltas representadas pelos que escapavam à exploração do trabalho. (Tinhorão, 2011: 30).

Até então, para as camadas populares, os períodos de tempo não dedicados ao trabalho eram dedicados majoritariamente às práticas religiosas e ao descanso. Porém, esses pilares não seriam mais suficientes para sustentar a complexidade do novo homem urbano. Aumentava, conforme o indivíduo moderno surgia, o anseio por entretenimento e esclarecimento. Nesse momento, a canção popular moderna, com todos os seus atributos, reunia requisitos para imbuir-se da função de levar entretenimento e inspiração às massas urbanas.

Hoje, passado o século XX, essa função atribuída à canção popular moderna nos parece óbvia. Contudo, o conceito de lazer, hoje consolidado, 
foi resultado de um longo processo histórico que se desenrolou ao longo da Modernidade:

no início do século XVII, o divertimento era associado com a hospitalidade demonstrada aos visitantes. Somente perto de 1650 o termo adquiriu um sentido adicional de algo interessante ou divertido, e apenas no início do XVIII certas performances (...) puderam ser descritas com «divertimento»

(Briggs e Burke, 2004: 74).

No século XIX, a já consolidada canção popular moderna não seria apenas elemento constitutivo fundamental da cultura popular, mas também produto importante do entretenimento urbano. Vale lembrar que, nos primórdios da Idade Moderna, a música com função de lazer ainda fazia parte de um grande conjunto de práticas populares variadas e pouco distintas entre si. Nos espetáculos de entretenimento:

profissionais de diversões certamente apresentavam um espetáculo de variedades. Um «comediante» não se restringia a papéis cômicos. Um «tocador» (...) podia tocar instrumentos, desempenhar um papel, fazer o bobo ou tudo isso ao mesmo tempo. Ele precisava ser um mestre em mímica e prestidigitação.(...). Um bufão ou palhaço podia cantar ou improvisar versos, esgrimir ou dançar numa corda, fazer acrobacias ou malabarismos com bolas no ar, e o mesmo acontecia com um menestrel (Burke, 2009: 136).

O mesmo ocorria em relação aos espaços para as apresentações - ainda que estalagens e tavernas reunissem apresentadores e público já a partir do século XVI. Como os profissionais do entretenimento eram poucos e seu alcance limitado (as populações só deixariam de ser majoritariamente rurais no final do XVIII, com a Revolução Industrial), a maioria deslocava-se em espetáculos itinerantes, como ocorre ainda hoje no circo. Não estava consolidada ainda a figura moderna do promotor, empresário e produtor. Assim, além da destreza em diversas formas de encantar o público, esses profissionais foram gradualmente desenvolvendo um forte senso mercantil ${ }^{1}$.

Embora não seja possível apontar apenas uma metrópole como berço dessa nova música das massas, destaco o pioneirismo luso-brasileiro das modinhas e lundus-canções. Ambos surgiram quase um século antes das demais formas típicas da canção urbana: a canção do teatro de vaudeville francês e a canzone napoletana.

\section{Pioneirismo luso- \\ -brasileiro na canção popular moderna}

Por volta de 1700, Paris (com meio milhão de habitantes), Nápoles (com 215 mil) e Lisboa (com 188 mil) figuravam entre as 5 cidades europeias com maior população. Grandes obras eram realizadas para aprimorar a

1 Esses cantores muitas vezes dispunham de uma série de ilustrações para as suas baladas e uma vareta para chamar a atenção do público, sem mencionar os exemplares das próprias baladas, que vendiam depois da apresentação, pois além de artistas eram também mascates e «comerciantes de baladas» (Burke, 2009, p.138). 
infraestrutura das cidades, aumentar áreas úteis, permitir o cultivo de alimentos em larga escala, o abastecimento de água e facilitar o trânsito de pessoas e mercadorias. Essas obras eram tocadas por funcionários livres e assalariados de diversos níveis sociais, de engenheiros a carregadores, cujas famílias consumiam produtos e contratavam serviços prestados por toda sorte de agricultores, produtores, artesãos e comerciantes. Ao passo dessa constante modernização das cidades, surgiriam também novas demandas por cultura e entretenimento, impulsionada por grupos com poder aquisitivo e interesses distintos (Hohenberg e Lees, 2009). As formas ideais de lazer não seriam, portanto, apenas coletivas, mas deveriam atender a nichos sociais específicos.

As novas formas de recepção da música urbana tornavam-se, assim como sua autoria, individuais, inserindo a canção popular moderna em um complexo sistema cultural e econômico baseado em localidades e contextos. Ao ser alçada a bem de consumo típico de importantes centros urbanos, a canção começaria a tomar diferentes formas, baseadas nas demandas específicas de cada estrato ou grupo social. As criações alimentavam-se da pluralidade de influências culturais típicas dos próprios impérios, estados-nação ou regiões que tinham, nessas cidades, seu núcleo. $\mathrm{O}$ alcance territorial e o impacto desses sistemas ficariam nítidos no aparecimento das modinhas e lundus, uma fusão de ritmos africanos com melodias europeias ocorrida em solo brasileiro.

O lundu era um gênero instrumental tipicamente dançante, fusão entre a umbigada dos terreiros africanos e a coreografia tradicional do fandango ibérico. Existia também o lundu-canção, cujas letras, já no espírito da canção popular moderna, satirizavam ou contestavam a ordem estamental da sociedade colonial (Monteiro, 1998: 87). A modinha, por sua vez, tem sua origem disputada por duas teorias: Mário de Andrade afirma que ela surgiu com base nas canções eruditas portuguesas no século XVIII e somente no XIX teria chegado ao Brasil, um processo «absolutamente raríssimo de uma forma erudita ter passado para o popular» (Andrade,
1964: 8.). Tinhorão (1998; 2011), por outro lado, afirma que o processo se deu de forma contrária, sendo responsável pelo feito o mulato Domingos Caldas Barbosa. Lereno, como Domingos era conhecido, apresentara, na década de 1770 , suas modinhas à corte lusitana e impressionara os músicos eruditos presentes não só por seu canto melódico e sentimental, mas, principalmente, pelo fato de que «ousava dirigir-se diretamente às amadas com uma intimidade chocante para uma sociedade de costumes fundados na separação dos sexos.» (Tinhorão, 2011: 163.).

Sendo ou não criador do gênero, Lereno, em seu estilo de cantar os próprios versos na sincopada rítmica afro-brasileira, e com sua atitude ousada frente ao público, deu forma à modinha. Temos, assim, o caso atípico da colônia influenciando uma criação cultural que tomaria contornos finais na metrópole.

Uma parte da explicação para essa inversão pode estar no processo de formação do que as elites convencionaram chamar de popular, e que fez com 
que o termo aceitasse interpretações tanto positivas quanto negativas. Em uma Europa de países ainda em processo de consolidação, o interesse pelo folclore tinha uma dupla função política: criar, ainda que artificialmente, um senso de pertencimento coletivo em torno dos estados nacionais recém-criados e, por outro lado, uma forma de resistir às imposições culturais de estados vizinhos. Da mesma forma, o exotismo servia a duas funções similares: provava, quando conveniente, a superioridade frente à barbárie do estrangeiro e, ao incorporar influências exóticas, mostrava o poder e extensão do domínio da civilização ${ }^{2}$.

Por fim, há outro fator essencial para a aceitação das práticas musicais da colônia brasileira em Lisboa. Se as populações das metrópoles europeias modernas, como já dito, estavam dispostas em intrincados arranjos de relações sociais baseadas em novas

2 Para uma discussão aprofundada sobre as funções do folclore e do exotismo no contexto cultural da Europa Moderna, ver Dahlhaus (1970). Burke $(2009 ; 2010)$ aponta ainda que ambos eram também reações contra o elitismo, a ênfase racional e a iconoclastia do Iluminismo. divisões do trabalho, há de se reconhecer que havia muito de colônia dentro da própria metrópole. Assim, explica-se a sincronia no aparecimento desse tipo de canção em Portugal e no Brasil ${ }^{3}$.

\section{A canzone napoletana \\ e o mercado do entretenimento}

Se a empreitada luso-brasileira de lundus e modinhas é considerada pioneira dentre as formas de canção popular moderna, o surgimento da canzone napoletana foi marcado por uma revolução cultural que gerou também profundas transformações econômicas. Diferentemente de Lisboa

3 Era como se (...) documentasse o fato de, embora criados na colônia, os sons chegados descalços - os escravos levados do Brasil não usavam calçados - encontrarem em Lisboa imediata aceitação nos bairros pobres, certamente também, estes, redutos de gente matizada por séculos de cruzamentos raciais. (...) Seria pois, desse vaivém de castelhanos e portugueses, entre a metrópole e as suas colônias, que resultaria não apenas a oportunidade de intercâmbio gerador de novas criações culturais na área do lazer das baixas camadas urbanas, mas também o fenômeno da quase simultaneidade na notícia do aparecimento de tais novidades (Tinhorão, 2011: 147). (politicamente soberana desde a reconquista frente aos mouros no século XII), Nápoles foi, durante toda a Era Moderna, constantemente invadida e disputada por sua localização estratégica no Mediterrâneo. Porém, as turbulências políticas que duraram até a unificação italiana, não impediram a cidade de sintetizar suas diferentes influências culturais para tomar parte na história do surgimento da canção popular.

O período entre os séculos XV e XVIII teve, em Nápoles, um dos maiores centros de formação musical de toda a Europa. Na época, o ensino de música litúrgica em conservatórios financiados pela Igreja Católica era prática comum. Além disso, a expansão da ópera como gênero dominante na cultura musical da Europa ocidental teve, à época, grande influência napolitana. Essa forte herança musical foi preponderante no surgimento da canzone napoletana como produto cultural (Prete, 2013: 138).

$\mathrm{O}$ aquecimento da demanda por serviços musicais entre a população napolitana deveu-se também ao 
processo de urbanização pelo qual a cidade passou na época, assim como ocorreu em Lisboa Ao mesmo tempo, desenrolavam-se os processos históricos que permitiram a expressão da individualidade por meio da criação musical nas classes inferiores. Ambas as transformações foram sintetizadas de forma ainda mais clara no surgimento da ópera buffa, que ocorreu em Nápoles, no começo do século XVIII.

Se a ópera tradicional era o espaço das grandes narrativas de reis, heróis e deuses, a ópera buffa era o lugar dos personagens cotidianos. Se, na ópera séria, o drama daria o tom, na buffa, a comédia e a sátira prevalecem. Enquanto a ópera tradicional era encenada na língua do rei ou na dos librettistas da nobreza, a buffa podia ser apresentada nos idiomas ou dialetos do povo. Assim, em um ambiente em que a demanda popular por entretenimento em forma de música só aumentava, até os gêneros mais ligados à nobreza se popularizavam. Essa popularização era também impulsionada pela força das ideias iluministas que, entre outras ideias, sugeria a emancipação do indivíduo, a liberdade de expressão e o fim das autoridades tradicionais.

Assim, a convergência desses movimentos criou um ambiente favorável à expansão da canção popular, dando novo vigor econômico para a cidade e projetando-a na cena cultural internacional (Prete, 2013: 159). $\mathrm{Na}$ primeira metade do século XIX, o sistema cultural da canzone napoletana estava estabelecido de tal forma que foi institucionalizada, em 1835, uma competição anual de canções, o Festival de Piedigrotta. Na primeira edição, a canção Te voglio bene as$s a i^{4}$ foi a vencedora. $\mathrm{O}$ surgimento do festival é o marco da instalação de um sistema que enxergava a música como produto comercial. Dentro desse sistema, o público napolitano passou a testemunhar uma sinergia cada vez maior entre música e entretenimento (Ravveduto, 2013), levando a uma

4 Curiosamente, a autoria da canção foi, segundo Scialò (1998), erroneamente atribuída a Donizetti, é sabido apenas que a letra é de autoria de Raffaele Sacco. Atribuir autoria com precisão nos primórdios da canção popular era tarefa difícil. Para uma discussão do tema em terras brasileiras, ver Longo (1999). forte espetacularização da canção popular moderna napolitana (Sommaiolo, 2013).

Nápoles, na primeira metade do século XIX, era um ambiente propício para a sobreposição e a pluralidade de expressões estéticas. Assim como em Paris e Lisboa, as paisagens sonoras napolitanas fundiam-se para fazer desse grande centro urbano solo fértil para diversas formas de manifestações culturais. Dessa forma, a canção napolitana permaneceu como marca permanente de identificação geográfica e cultural.

\section{A chanson parisiense e a consolidação do público moderno}

Se Nápoles foi marco no estabelecimento da canção como parte de um sistema cultural, foi na Paris do século XIX que o público desse sistema finalmente se consolidou. As bases para tal solidificação, contudo, remontam à baixa Idade Média. A tradição francesa em apreciar canções remonta aos romances de cavalaria, nos quais as narrativas épicas sobre feitos heroicos 
de honrados cavaleiros se desenrolavam em versos. No século XVI, o romance de cavalaria desdobrou-se em novas formas literárias e, na França, espalhou-se por entre a nobreza também sob a forma da canção cortesã, com versos transformados em estrofes musicadas. Essa forma, que já incluía temas satíricos, burlescos e, principalmente, românticos, era conhecida também como voix de ville, ou voz da cidade (Brooks, 2006: 65-6).

Por sua vez, o etnomusicólogo Julien Tiersot, em sua história da canção popular francesa de 1889, reuniu sob o termo chanson populaire tanto as canções cortesãs quantos as canções populares das ruas, conhecidas «no século XVI como voix de ville ou vaudeville» (Tiersot, 1889: 450). Pesquisas mais recentes apresentam como dúbia a origem do termo vaudeville, pois sua etimologia mesclaria dois gêneros diferentes: o vau de vire (canções provincianas da Normandia) e o voix de ville (canções urbanas cortesãs de Paris) (Alden, 2008: 64-5). Independentemente das características que aproximavam ou distinguiam essas formas iniciais, foi no ambiente urbano parisiense do século XIX que elas seriam sintetizadas para formar a canção popular moderna de caráter francês.

A versão francesa da canção popular lançou as bases do que viria a ser, posteriormente, o teatro de vaudeville, gênero de entretenimento típico da burguesia, elemento-chave da cultura de entretenimento de massa instalada na capital francesa. No vaudeville, uma narrativa central, geralmente uma comédia sobre o cotidiano, era entremeada por canções, números de dança e outros atos conhecidos como variedades. $\mathrm{O}$ espaço do vaudeville, por definição, era o teatro.

O contexto parisiense interessa menos pela canção em si e mais pelo ambiente social do qual ela emerge. Foram particularmente decisivos o grande abismo econômico entre as classes e o latente choque entre a multidão e o indivíduo, gradativamente instalados na cidade durante o século $\mathrm{XIX}^{5}$. Os parisienses da época viviam

\footnotetext{
5 A Revolução Industrial, nascida na Inglaterra, instalou-se na França de forma gradual entre 1815 e 1860 (Lévy-Leboyer, 2008).
}

em um equilíbrio entre o anseio das identidades individuais e $\mathrm{o}$ anonimato imposto por uma metrópole industrial de mais de 600 mil habitantes. Por um lado, os princípios revolucionários de liberdade, igualdade e fraternidade haviam, no final do século anterior, despertado a busca por afirmação individual. Por outro, esse desejo era reprimido pelas multidões nas ruas e pelo trabalho massificante nas fábricas.

A cidade das grandes galerias, largas calçadas, magazines de moda, comodidades urbanas (e que, ao final do XIX, tornar-se-ia o espaço da Belle Époque) era, na metade do século, a mesma dos insalubres bairros operários descritos por Victor Hugo, em Os Miseráveis (1862). As revoluções francesas de julho de 1830 e de fevereiro de 1848 (essa, estopim da Primavera dos Povos) foram fortalecidas pelas reivindicações proletárias (Hobsbawm, 2009) que refletiram a constante tensão vivida por uma «população fervilhante e furtiva

Outro fator crucial para determinar o abismo socioeconômico entre os parisienses foi a reforma urbana levada à cabo por Haussmann, entre 1853 e 1870. 
que Paris deixa viver nos becos pavorosos, dissimulando-a bem atrás dos museus e dos palácios» (Janin apud Bresciani, 1982: 13).

Nesse contexto, o entretenimento do vaudeville (bem como as formas subsequentes de teatro musicado, como o teatro de boulevard) mostrou-se, ao mesmo tempo, válvula de escape e ponte entre distintas realidades, crescendo como produto cultural atrelado a novas formas de representação social. O relaxamento das tensões cotidianas se dava por meio das narrativas romântico-sexuais e da sátira aos costumes, temas centrais do vaudeville. Além disso, em muitas das histórias, orbitavam temas caros às aspirações sociais do público burguês, como o consumo (de roupas, charutos, sapatos e perfumes), a vida de aparências e os eventos sociais (bailes, salões e jantares). Não à toa, os finais felizes de vaudeville «quase sempre representavam a vitória do (...) excesso» (Teni, 2006: 242-3).

É também da Paris urbana da segunda metade do século XIX a figura doflâneur, o homem que vagueia pelas ruas em busca de prazer (Shaya, 2004). O flâneur perambula entre os boulevards e galerias, passeia lentamente pelos parques e aprecia as vitrines dos magazines, resiste à homegeneização imposta pela cidade, destacando-se da massa proletária. Assim, o flâneur «é um homem na multidão mas não um homem $d a$ multidão» (Teni, 2006: 49). Essa figura, descrita pela poesia de Baudelaire, é o símbolo do indivíduo que busca entretenimento e inspiração naquilo que a modernidade transformou em produto. Ele é, portanto, o ouvinte da canção popular moderna.

Paris é responsável não apenas pela consolidação do público da canção, mas também pela criação das formas modernas de consumo. As práticas de recepção musical estavam condicionadas a uma rede conceitual formada por linhas de transportes, estabelecimentos e peças de mídia. Ou seja, as linhas de bondes, inauguradas em 1855, expandem os núcleos sociais dos quarteirões para os bairros e dos bairros para as zonas periféricas, permitindo ao público explorar a diversidade de opções de entretenimento musical. Atrações distintas apresentam-se nos cafés, salões, teatros e restaurantes que, interligados por galerias, boulevards e passeios, eram visitados por toda sorte de público. Jornais, cartazes, folhetins e caricaturas, ao divulgar as atrações, completam a trama sobre a qual a vida urbana flui:

para o flâneur perfeito, para o espectador apaixonado, é uma imensa alegria fazer seu lar no coração da multidão, no vai e vem do movimento, entre o fugitivo e o infinito. Estar longe de casa e, ainda assim, sentir-se em casa em qualquer lugar; ver o mundo, estar no centro do mundo e, ao mesmo tempo, manter-se escondido dele (Baudelaire, 1995: 9).

O teatro musicado com origem no vaudeville é ponto central na rede urbana sobre a qual indivíduos, adeptos ou não da flânerie, constroem sua personalidade e dialogam com o entorno. No teatro, o parisiense ovaciona membros de seus grupos de pertencimento; caçoa dos demais para distinguir-se; maldiz para reconfortar-se; aspira novas posições e refuta antigas. O vaudeville, ao encenar o cotidiano de seu público, faz 
com que o frequentador veja a si mesmo no palco podendo, assim, redefinir-se à medida em que se observa.

Embora tenha abordado nesta pesquisa as três cidades de maneira isolada: Lisboa - no intercâmbio com o Rio de Janeiro - como pioneira da canção popular moderna; Nápoles, como exemplo da emergência dos serviços de entretenimento; Paris, como cidade típica do homem moderno, criador e público da canção urbana é importante assinalar que, apesar das cenas musicais autônomas em cada cidade, houve nelas uma coexistência simultânea dos três aspectos estudados aqui separadamente. Assim, o estabelecimento de um mercado de entretenimento não foi exclusividade de Nápoles, ocorreu também em Lisboa e Paris. Da mesma maneira, Nápoles e Lisboa, como Paris, foram todas habitat do homem moderno.

\section{A canção como}

representação individual em um mundo em expansão

Como se vê, rigorosas mudanças nas formas de vida das populações europeias afetaram os modos de produção, os locais do habitar, as formas de relacionamento social, as crenças, as noções de estranhamento e familiaridade, alterando, assim, o entendimento prévio do existir. Os contemporâneos dessas épocas viram, acima de tudo, movimentos que, independentemente de sua natureza e características, mostraram-se antagônicos ou contraditórios: o nascimento da ideia de arte, mas também o cientificismo; o neocolonialismo e imperialismo, mas também o Iluminismo; a expansão marítima, mas também a concentração urbana; o telescópio e o microscópio, como novas formas de explorar distâncias e proximidades; a reforma católica e o agnosticismo; e, sobretudo, o surgimento da subjetividade e do operário, do indivíduo e da multidão.

Ao cruzar as fronteiras anteriores em todas as direções possíveis, tais fenômenos criam uma grande expansão de sentidos e possibilidades que empurrou o homem moderno em busca do novo. Este ensaio é uma história de como, ao longo da Idade Moderna, a música popular foi moldada por uma sequência de novos acontecimentos: a emergente reciprocidade das influências culturais nas relações coloniais entre Rio de Janeiro e Lisboa; a paulatina inclinação ao entretenimento da música napolitana; e a crescente pluralidade e dinamismo da vida urbana parisiense. O novo é, de fato, a questão: as canções do século XVI são chamadas de novas novidades, as do XVIII, modas novas. Não à toa, moda já significava tanto uma canção quanto as mais novas tendências de consumo. E, ao uni-las, a canção de Paris tornou-se pioneira na fusão entre tradição e modernidade.

Lisboa, Nápoles e Paris reuniram, à sua maneira e ao seu tempo, as condições que levariam ao surgimento e à consolidação da canção popular moderna: a sobreposição e multiplicidade de sentidos; a efervescência e pluralidade cultural; o vigor econômico; o equilíbrio entre anonimato e protagonismo; as tensões sociais e a consequente demanda por seu relaxamento. As três cidades contribuíram com o florescimento de uma expressão musical predominante no Ocidente, seja no son cubano, na MPB brasileira, no folk americano, no cantautore 
italiano, na chanson francesa ou no reggae jamaicano.

Os eventos e as reflexões aqui narrados fazem parte de um processo maior, que se ocupa não somente das relações humanas mediadas pelo sons e pela música. Esse processo representa também a transição entre as formas centralizadoras de produção de sentido e as culturas populares modernas, que se apresenta de duas maneiras:

primeiro como um mercado de alta literatura, novelas e novidades, nas quais as mensagens estão focadas no receptor ao invés do emissor, para atender a expectativa do público por entretenimento e edificação; e também, como um mercado do gênio (...) (Sloterdijk, 2014: 750-1).

A canção popular moderna habita, portanto, um sistema de transferência de motivações individuais que se retroalimenta e é projetado em larga escala na sociedade. Os frequentadores dos teatros parisienses, dos cafés-cantantes napolitanos e dos casarões e pagodes lisboetas encontraram na canção uma forma de cultivar sua recém-adquirida individualidade. Da mesma forma, essa noção de individualidade nutre autores (em seu recém-adquirido status de artistas) para criar canções expressando sua identidade e, consequentemente, para servirem à massa (agora rebatizada de plateia). Na raiz desse movimento cíclico de feedback, que eleva autores e público de forma proporcional, vão surgir fenômenos de culto ao artista, como a «lisztomania» na década de 1840, a «beatlemania», mais de um século depois, assim como todas as demais versões contemporâneas de catarses coletivas centradas em artistas pop.

«O homem privado pisa o palco da história», metáfora de Walter Benjamin (1991: 37) sobre a ascensão do indivíduo no século XIX, alcança, no caso da canção, também quem está diante do palco: a plateia. No surgimento da canção popular moderna, palco e plateia são protagonistas, seja expressando subjetividade através canção composta, seja entretendo-se por meio dela. A canção nasce, assim, como instrumento de definição e amplificação do indivíduo em um mundo em constante expansão ${ }^{6}$.

\section{Referências bibliográficas}

Adorno, T. W. (1983). O fetichismo na música e a regressão da audição. In: Banjamin, W. et al. Textos escolhidos. 2. ed. São Paulo: Abril Cultural.

Alden, J. (2008). Excavating Chansonniers: Musical Archaeology and the Search for Popular Song. The Journal of Musicology, 25(1).

Andrade, M. (1964). Modinhas Imperiais, São Paulo, Martins Fontes.

Baudelaire, C. (1995) The Painter of Modern Life and Other Essays. Phaidon Press.

Benjamin, W. (1991). Paris, Capital do século XIX. In: Benjamin, W. Sociologia. 2.ed. São Paulo: Ática.

6 A constante expansão do mundo a que me refiro traduz-se nas metáforas usadas por Peter Sloterdijk na trilogia Esferas (Bolhas, 2011; Globos, 2014; Espumas 2016), a serem usadas como instrumento para examinar as relações humanas com a música na tese $O$ Ser Sonoro, em fase de produção, e da qual o presente trabalho faz parte. 
Bresciani, M. S. (1982). Londres e Paris no Século XIX: O espetáculo da pobreza. São Paulo: Brasiliense.

Briggs, A. \&Burke, P. (2004). Uma História Social da Mídia. São Paulo: Zahar.

Brooks, J. (2005). Chivalric romance, courtly love and courtly song: female vocality and feminine desire in the word of Amadis de Gaule. In LaMay, T. Musical Voices of Early Modern Women: Many- headed melodies. Abingdon: Routledge.

Burke, P. (2010). Cultura popular na Idade Moderna: Europa 1500-1800. O São Paulo: Companhia das Letras.

Dahlhaus, C. (1991). Nineteenth-Century Music. California: University of California Press.

Hobsbawm, E. (2009). A Era das Revoluções - 1789, 1848. São Paulo: Paz e Terra.

Hohenberg, P.M.; Lees, L.H. (2009). The Making of Urban Europe, 1000 1994. Harvard University Press.

Lévy-Leboyer, M. \& Bourguignon, F. (2008). The French Economy in the Nineteenth Century: An essay in econometric analysis. Cambrigde: Cambridge University Press.
Longo, M. M. (1999). Memórias do cais: Caymmi, canções e fontes. Literatura e sociedade, 4, 68-77.

Minnis, A. (2012). Medieval Theory of Authorship. Pennsylvania: University of Pennsylvania Press.

Monteiro, M. (1998). A Construção do Gosto: Música e sociedade na corte do Rio de Janeiro - 1808-1821. Rio de Janeiro: Ateliê Editorial.

Prete, R. Del (2013). La Città Del Loisir: Il Sistema Produttivo Dello Spettacolo Dal Vivo A Napoli Tra ‘800 E '900. In Pesce, A. \& Stazio M. La Canzone Napolitana - Tra Memoria E Inovazione: La città del loisir (pp. 121-164). Consiglio Nazionale Delle Ricerche.

Ravveduto, M. (2013). La metropoli neomelodica. In Pesce, A. \& Stazio M. La Canzone Napolitana - Tra Memoria E Inovazione: La città del loisir (pp. 415-451). Consiglio Nazionale delle Ricerche.

Schmiesing, A. (2014). Disability, Deformity, and Disease in the Grimms' Fairy Tales. Wayne State University Press.

Scialò, P. (1998). La Canzone Napoletan. Roma: Newton.
Shaya, G. (2004). The Flaneur, the Badaud, and the making of a mass public in France, circa 1860-1910. The American Historical Review.

Sloterdijk, P.(2014). Globes: Spheres Volume II: Macrospherology. Los Angeles: Semiotext(e) .

Sommaiolo, P. (2013). Il café-chantant e la spettacolarizzazione della canzone a Napoli tra la fine dell'Ottocento e la prima guerra mondiale. In: Pesce, A. \& Stazio, M., La canzone napolitana - tra memoria e inovazione: la città del loisir (p.183-204). Roma: Consiglio Nazionale delle Ricerche, Teni, J. (2006). A Genre for Early Mass Culture: French Vaudeville and the City, 1830-1848. Theatre Journal, $58(2)$.

Tiersot, J. (1989). Histoire de la Chanson Populaire en France. Paris: Plon.

Tinhorão, J. R. (1998) História Social da Música Popular Brasileira. Rio de Janeiro: Editora 34. 